\title{
Bonaparte dos poetas: notas sobre as figurações napoleônicas no Romantismo brasileiro
}

\author{
Vagner Camilo \\ Universidade de São Paulo \\ vcamilo@usp.br
}

Resumo: Este ensaio examina a presença de Napoleão Bonaparte na literatura anterior e posterior à Independência do Brasil (1822), elegendo o enfoque dado ao corso por alguns poetas do período, filiados, em sua maioria, ao Romantismo. O principal objetivo é destacar a mudança de expectativa nesse enfoque, tomando por referência o contexto histórico-político em que se inscreve essa produção poética.

Palavras-chave: Romantismo, poesia, Napoleão Bonaparte, nação.

\section{The poets' Bonaparte : Notes on the Napoleonic Figurations in \\ BRASILIAN ROMANTICISM}

Abstract: This essay examines the presence of Napoleon Bonaparte in the literature before and after the Independence of Brazil (1822) by discussing the way some poets of the period, mostly related to Romanticism, focused their work on the corso. The paper's main aim is to highlight the change in expectations of such focus, which can be accounted for in terms of the historical and political context that frames such poetic production.

KEYWORDs: Romanticism, poetry, Napoleon Bonaparte, nation. 
Este ensaio examina a presença de Napoleão Bonaparte na literatura anterior e posterior à Independência do Brasil (1822), elegendo o enfoque dado ao corso por alguns poetas do período, filiados, em sua maioria, ao Romantismo. Interessa, particularmente, destacar à mudança de expectativa operada nesse enfoque, compreendida à luz do horizonte histórico-político em que se inscreve essa produção poética. Para tanto, julgo por bem recorrer, de saída, a uma breve introdução ao contexto de emergência desse movimento artístico-literário no país.

O movimento romântico no Brasil aliou-se ao empenho do país recémindependente para consolidar sua autonomia, fornecendo a mitologia pátria de que a jovem nação carecia não só para afirmar sua identidade própria, distinta da antiga metrópole, mas também para fortalecer o esforço centralizador do Império e garantir, pelo menos no plano da cultura, a tão desejada unidade nacional. Esse esforço centralizador de um país de proporções continentais, marcado cultural e etnicamente por grande diversidade regional, se justificava pelo temor de separatismos, a exemplo do que ocorrera com as antigas possessões espanholas, fragmentadas nas várias repúblicas hispano-americanas com o processo de independência. Daí a urgência de se forjar um mito unificador para a nação recémemancipada que persistia no modelo monárquico de governo.

Isso explica a característica mais marcante assumida pelo Romantismo no Brasil: o nacionalismo, que, em tese, antecedeu esse movimento artísticoliterário, mas veio a encontrar nele uma justificativa e um novo alento (Cândido 7-44). Contribuíram para a tarefa de dotar o país de uma mitologia, uma literatura e uma historiografia próprias os membros das elites e das camadas médias cooptadas que se sujeitavam ao jogo político da constituição do Império, empenhando-se em garantir as condições mínimas para a inserção do Brasil no concerto das nações civilizadas (Puntoni 119-30). A parte mais significativa da inteligência nacional estava vinculada ao Instituto Histórico e Geográfico Brasileiro (IHGB), fundado em 1838, nos moldes do Institut Historique de Paris (1834), a que pertenciam intelectuais como Eugène de Monglave e Jean-Baptiste Debret, visitantes influentes no Brasil, que estabeleceram a ponte e a intensa troca cultural entre os membros do instituto brasileiro e seu congênere francês. Transferido depois para o Paço Imperial, o IHGB tinha seus encontros presididos pelo próprio D. Pedro II, que na qualidade de "monarca esclarecido e amigo das letras", tomava parte nos debates e interferia 
diretamente nas atividades e pesquisas aí desenvolvidas e custeadas por ele. Assim, meio anacronicamente, criava-se uma intelectualidade áulica, de corte, nos moldes das antigas academias ilustradas dos séculos XVIIXVIII, tendo ao centro a figura do Imperador-mecenas. O Instituto tornou-se então uma espécie de think tank (Treece) que estabelecia um vínculo essencial entre a vida intelectual do país e a esfera política da oficialidade estatal, desempenhando um papel central na construção da unificação nacional em nível cultural (Treece 129; cf. também Schwarcz 127). Como afirma Salgado Guimarães, coube ao IHGB a difícil tarefa de produzir uma historiografia capaz de forjar uma visão homogeneizadora de um país marcado pela heterogeneidade (brancos, negros, índios, mulatos; negros livres, escravos etc.). Para essa homogeinização, gestada no interior das elites ilustradas, acreditava-se ser necessário, primeiramente, o esclarecimento dos que estavam no topo da hierarquia social, para que estes se incumbissem, depois, do esclarecimento dos demais (Salgado Guimarães 5-27).

A historiografia do IHGB definia a Nação brasileira como continuadora da tarefa civilizadora iniciada pela colonização portuguesa. Enquanto na Europa, Nação e Estado eram tomados como esferas distintas, aqui eles foram pensados como formando uma unidade juntamente com a Coroa. Além do que, o conceito de Nação compreendia apenas os brancos - diferentemente, portanto, da abrangência do conceito em contexto europeu-. Tendo por base tal concepção restritiva e tal unidade com Estado e Coroa, compreende-se que o outro da Nação brasileira fosse, externamente, as repúblicas latino-americanas (com a visão monarquista empenhando-se em identificar republicanismo e barbárie) e, internamente, os índios e, sobretudo, os negros (empecilhos à realização plena do projeto civilizador) (ibidem). No que diz respeito especificamente ao índio, travouse, aliás, acirrado debate historiográfico no interior do IHGB, polarizando em campos opostos historiadores e literatos (poetas e escritores) em torno da viabilidade da nação brasileira estar representada pelo indígena. Isso porque a forma mais celebrada de literatura nacional no Romantismo brasileiro foi o indianismo, cujo período áureo correspondeu às décadas de 1840 a 1860, tendo como principais expressões Antonio Gonçalves Dias na poesia e José de Alencar na ficção. Nem todos os intelectuais, dentro ou fora do IHGB, pactuavam com essa tendência, como era o caso do jornalista e historiador João Francisco Lisboa (conhecido como o cético e satírico Timon maranhense) e o historiador Francisco Adolfo de Varnhagen, que 
criticavam duramente os "patriotas caboclos" por elegerem o indígena como antepassado do brasileiro, o que seria uma forma de atrelar as origens do estado nacional à barbárie, ao invés de reconhecê-lo, de forma devida, como prolongamento da civilização europeia (portuguesa) nos trópicos. Longe do bom selvagem rousseauniano evocado pelos indianistas românticos, seus detratores tendiam, muito mais, a identificar o índio ao homem lobo de Hobbes (cf. Ricupero 142). Varnhagen chegava a ver nos índios um povo sem direito à terra, pelo sua condição nômade, além de seres falsos, infiéis e inconstantes, "humanidade bestial" alheia à moral e ao pacto social, por ignorarem as instituições do Império. Isso dava razão de sobra para a guerra justa impetrada contra eles nos primórdios da colonização e levava Varnhagen a estender para o presente a civilização pela força como forma de sujeitar o índio ao controle do branco e liberar suas terras para exploração por colonos brasileiros e imigrantes (cf. Treece).

Como nota Bernardo Ricupero, essa polêmica em torno do indianismo constitui, na verdade, "um debate entre os campos nascentes, e ainda pouco delimitados, da literatura e da história" (Ricupero 141). O fato é que, apesar de criticados por historiadores como Varnhagen, os poetas e escritores indianistas brasileiros alcançaram, todavia, sucesso e popularidade na imposição do índio como símbolo pátrio (Schwarcz 140), constituindo, assim, a principal vertente do nacionalismo romântico no Brasil. O temário indianista já encontrara antecedentes e grandes realizações na literatura do período colonial, em particular na literatura árcade, com os poemas épicos de Basílio da Gama (O Uragua ) e de Santa Rita Durão (Caramuru). Além disso, a imagem do índio passava a ser cada vez mais empregada como alegoria plástica e poética já nas festas oficiais do Brasil pré-independente de D. João VI, representando o país com uma dignidade equiparável às figuras mitológicas clássicas. Intensificou-se com a Independência, quando inclusive se tornou frequente a prática de adotar nomes e atribuir títulos indígenas para uma pretensa nobreza que se forjava anacronicamente em torno do Imperador (cf. Cândido 7-44).

Esses antecedentes favoreceram a acolhida dos ideais românticos ligados à valorização do exótico, do primitivo, do particular e do nacional. O exemplo decisivo do exotismo dos franceses, em particular de Chateaubriand (cujo Atala muito inspirou um dos maiores romances indianistas brasileiros: Iracema, de José de Alencar), não só agiu diretamente sobre a imaginação dos escritores, mas também estimulou a reavaliação da tradição e a contribuição literária local ao tema, levando a reinterpretar 
os referidos poemas épicos de Basílio e Durão segundo as aspirações românticas. Para essa reinterpretação, muito contribuiu o escritor e historiador francês Ferdinand Denis que apontava traços precursores do nacionalismo literário na literatura colonial, os quais caberiam aos românticos retomar e aprofundar.

Embora, no processo de formação do Brasil, a presença africana tenha sido mais decisiva, ela jamais poderia ser louvada pelos românticos, dada a condição aviltante a que se encontrava reduzido o negro como escravo. $\mathrm{O}$ índio, menos presente no cotidiano oitocentista, se prestava mais ao tipo de idealização exigida para um mito fundador. Além disso, argumentava-se que a identificação do índio como ancestral dos brasileiros era justificável na medida em que, muito antes da chegada dos portugueses, ele já se encontrava no território americano correspondente ao Brasil. Para essa ordem de argumento, muitas vezes se recorria a certa analogia com o caso francês, modelo de civilização para o Brasil, lembrando que, de acordo com certos historiadores liberais da Restauração, os verdadeiros franceses seriam descendentes dos gauleses conquistados e não dos francos invasores. Prova dessa analogia está no diálogo estabelecido por Alencar entre sua Iracema e a Norma de Bellini, justamente identificando a virgem (espécie de vestal) dos tabajaras com a sacerdotisa dos gauleses durante a dominação romana, além de o próprio Gonçalves Dias que, em "O gigante de pedra", compara expressamente ao gaulês o índio vitimado pelo colonizador ${ }^{1}$.

Para que se elevasse o índio à condição de mito nacional, foi necessário submetê-lo a uma espécie de deformação idealizante, eliminando dessa imagem tudo que contrariasse o estatuto de herói e os valores morais e cristãos da civilização ocidental. Para esse retrato idealizado, tomouse de empréstimo os atributos do cavaleiro medieval e da ética cortês (como a nobreza, a coragem, a lealdade, a justiça, o desprendimento... $)^{2}$, a fim de fazer o índio, como antepassado do brasileiro, equiparar-se

1 Para a analogia com o caso francês, ver Ricupero (153). Para o diálogo intertextual de Iracema com a ópera de Bellini, ver Ribeiro (405-413/476).

2 A sugestão dessa aproximação já consta de "Como se deve escrever a História do Brasil", trabalho premiado pelo Instituto, de autoria de Karl Friedrich von Martius, cientista alemão ocupado das coisas brasileiras que, ao sugerir a necessidade de um estudo cuidadoso da história dos índios, até mesmo pela possibilidade de tais investigações 
qualitativamente ao conquistador. Desse modo, o indianismo surgiu não só como passado mítico e lendário, mas também como passado histórico, nos moldes da Idade Média, de maneira que lenda e história se fundiram num esforço de suscitar um mundo poético digno. O temário indianista servia, assim, como compensação à inexistência de um passado medieval ligado ao país e tão valorizado pelos românticos europeus (cf. Cândido).

É bem verdade que muitos desses atributos da ética cortês já haviam sido antes associados ao índio por Montaigne, por exemplo, com quem os românticos brasileiros também dialogaram de perto. No caso do autor dos Essais, essa associação se justifica pelo sentido que ele atribui ao ímpeto guerreiro, que foi, inclusive, o principal aspecto da cultura indígena explorado pela poesia de Gonçalves Dias.

A descrição de combates frequentes entre tribos está presente em Jean de Léry, André Thevet e praticamente todos os cronistas e viajantes, assim como, no primeiro, consta a observação de que os índios não faziam guerras de conquista, já que terras e riquezas lhes sobravam, mas que eram movidos pelo desejo de vingança dos parentes mortos em combate. Montaigne retoma em seu relato a discussão sobre o ânimo guerreiro indígena, mas lhe atribui outra motivação: a guerra entre comunidades indígenas era nobre e generosa porque seu fundamento era a emulação na prática da virtude, fundamento esse que se ajusta claramente à imagem do cavaleiro medieval e à concepção da ética cortês (Arinos de Melo Franco 238ss).

Volto ainda ao processo da Independência. Para alguns historiadores, esse processo que pouco teve de participação popular, jamais assumindo um caráter verdadeiramente revolucionário, com a mobilização das classes populares, sendo quase um acordo intra-elites -ou "um desquite amigável", como lembra Oliveira Lima-, foi de certo modo gradualmente preparado desde o que se convencionou chamar de "inversão metropolitana", fenômeno talvez único nas relações coloniais, sem paralelos no caso da colonização espanhola ou inglesa. Trata-se da vinda da família real portuguesa para o Brasil, foragida em 1808, transferindo-se assim a sede da monarquia lusa da metrópole para a colônia, que passou a ser o eixo da

contribuírem para a produção de mitos, toma o exemplo das lendas sobre os cavaleiros medievais no espaço europeu. Cf. Salgado Guimarães (5-27). 
vida administrativa do Império lusitano. A razão dessa inversão deve ser buscada no contexto da Guerra Peninsular, com a invasão de Lisboa pelas tropas napoleônicas em 1807, devido ao fato de a Coroa portuguesa ter rompido o Bloqueio Continental que proibia o comércio com a Inglaterra. Sob a proteção da frota inglesa, o príncipe regente D. João VI, sua família e cerca de 10 a 15 mil pessoas embarcaram com todo o aparelho burocrático rumo à colônia sul-americana. A reviravolta ocasionada por essa transferência da corte portuguesa para o Rio de Janeiro mudou não só a fisionomia da cidade e a vida econômica e a comercial (com a abertura dos portos às "nações amigas", mais particularmente a Inglaterra), bem como a vida cultural da antiga Colônia, logo elevada à condição de Reino Unido de Portugal, Brasil e Algarves (1815). Além disso, modificou o quadro das relações internacionais no contexto da América do Sul, com a Coroa portuguesa realizando expedição à Guiana Francesa, incentivada pela Inglaterra, e concentrando sua ação na área do Prata, especificamente na Banda Oriental (atual Uruguai), que, depois de duas intervenções militares, com a derrota de Artigas, garantiu em 1821 a posse do território com o nome de Província Cisplatina.

Em suma, o que interessa destacar aqui, é que essa inversão metropolitana, que fez da antiga Colônia a sede do governo do império ultramarino português, logo elevada à condição intermediária de Reino Unido, para em seguida alcançar, sem grandes saltos ou sobressaltos, a Indepêndencia em 1822, foi precipitada justamente... pela invasão napoleônica! Com isso, nosso grande personagem histórico entra, finalmente, em cena, louvado pelos primeiros românticos, imbuídos do espírito e da missão de forjar a nacionalidade brasileira. É o que se pode observar com Antonio Gonçalves de Magalhães que marca o início do Romantismo brasileiro com a publicação tanto de seu livro de versos, Suspiros poéticos e saudades (em que presta homenagem a Napoleão em um dos poemas do livro) em 1836; quanto da edição revista Nitheroi revista brasiliense, dada a estampa em 1838 em Paris, mas sob os auspícios do imperador Pedro II.

Antes, porém, de passar a Gonçalves de Magalhães e demais poetas que se ocuparam de celebrar Napoleão em versos, importa registrar que a presença do corso no contexto histórico-político brasileiro ocorre no período que segue à Independência, consolidando-a, na iconografia e nos símbolos do primeiro reinado, a começar pela cena da coroação de 
D. Pedro I -que, aliás, mantinha, por intermédio de sua segunda esposa, Amélia de Leuchtenberg (ou Amélie Auguste Eugénie Napoléone de Beauharnais, neta de Joséphine de Beauharnais), um vínculo de parentesco com Napoleão Bonaparte-.

Quem cuidou da representação pictórica enaltecedora da cena da coroação de D. Pedro foi um dos integrantes da Missão Artística Francesa que veio ao Brasil a fim de fundamentar as bases de uma instituição de ensino em artes visuais na nova capital do reino, introduzindo os padrões estéticos do neoclassicismo num contexto em que persistia, ainda mais tardiamente, o barroco. Dentre os artistas que integram essa missão partidários de Bonaparte que, depois da queda deste em 1815, viram-se prejudicados pela volta dos Bourbons ao poder-, estavam Nicolas Taunay (outrora requisitado pelo próprio César para pintar cenas de batalhas, como as campanhas napoleônicas na Alemanha) e o já citado Debret, pintor histórico que, inspirado pelo modelo davidiano da pintura de cerimonial e, mais particularmente, pela famosa tela da coroação do imperador francês feita por seu mestre (Figura 1), empregou-a para figurar a coroação de Pedro I (Figura 2).

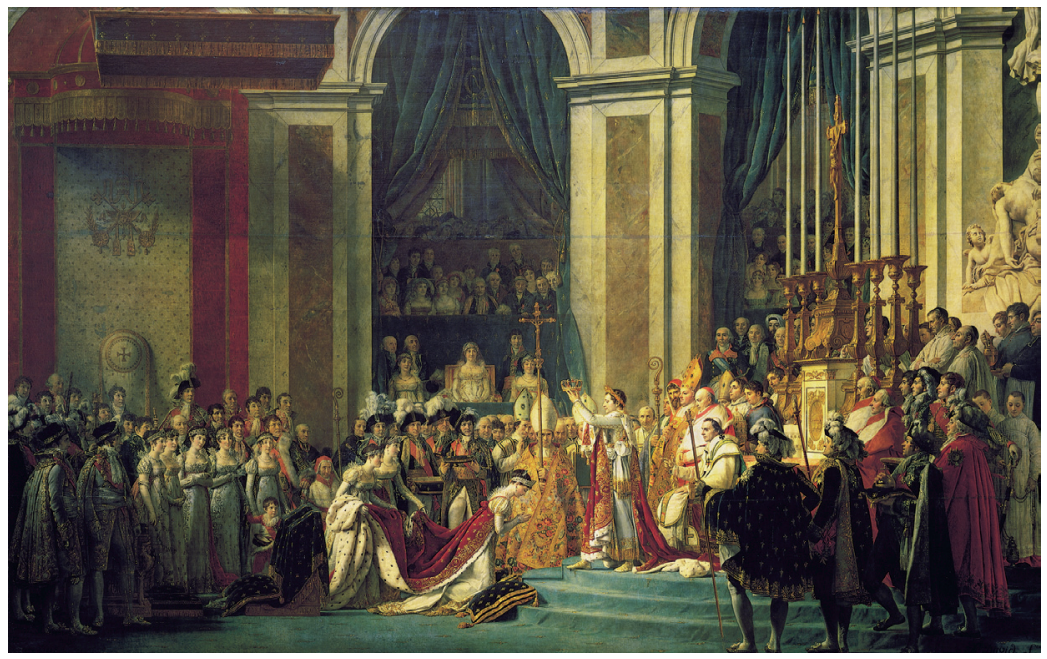

Figura 1. Jacques-Louis David, Sacre de l'empereur Napoléon et couronnement de l'impératrice Joséphine, à Notre-Dame de Paris, le 2 décembre 1804.

http://commons.wikimedia.org/wiki/File:Jacques-Louis_David,_The_ Coronation_of_Napoleon_edit.jpg 


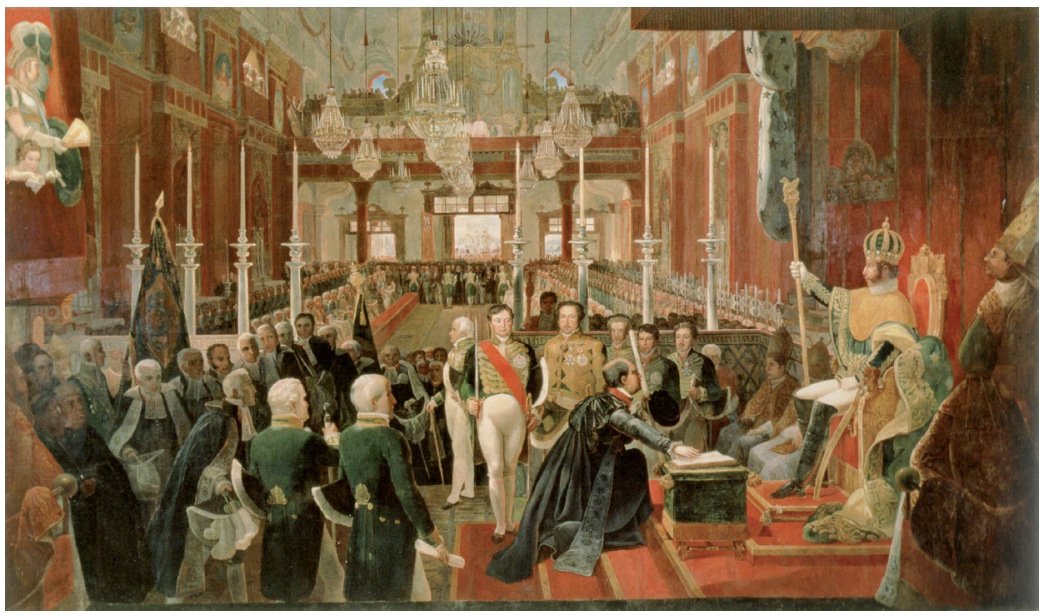

Figura 2. Jean Baptiste Debret, A Coroação de Dom Pedro I como Imperador do Brasil. http://upload.wikimedia.org/wikipedia/commons/4/43/Coroa\%C3\%A7ao_ pedro_I_001.jpg

Além disso, Debret contribuiu para a simbologia pátria ao criar a bandeira imperial mesclando, às referências localistas, ligadas à família real e à natureza do país, símbolos franceses, como o losango das bandeiras regimentais de Napoleão, trocando as cores azul e vermelha da França revolucionária pela verde e pela amarela, que simbolizavam as dinastias de Habsburgo-Lorena e dos Bragança.

Não me atreveria aqui a arriscar qualquer análise comparativa desses símbolos e pinturas, que fogem à minha alçada. Passo, assim, finalmente ao domínio do literário, e particularmente da poesia, retornando a Gonçalves de Magalhães.

No caso da revista publicada por ele, além de outros brasileiros que estudavam em Paris e que viriam a representar a $1^{a}$ geração romântica no Brasil, integrando depois a intelectualidade áulica sediada no IHGB, nota Pinassi que em toda a Nitheroi emana uma grande simpatia pela França, vista como a nação adotada em substituição à antiga metrópole, passando a ser tomada por guia. Lê-se, assim, na revista: "Com a expiração do dominio Português, desenvolveram-se as ideias. Hoje o Brasil é filho da civilização Francesa; e como Nação é filho desta revolução famosa, que balançou os tronos da Europa (...)" (em Pinassi 138). As histórias das duas nações passam a convergir, pois na 
revista, Magalhães, baseado nas ideias de Victor Cousin, vê a "Revolução Francesa como um divisor de águas da história brasileira, sendo a primeira fase (até 1808), anterior a sua intervenção, coberta de obscurantismo (...) Depois de 1808, a cena brasileira muda em consequência da política imperialista de Napoleão Bonaparte" (Pinassi 141). Em nota, diz Pinassi a esse respeito:

Chama a atenção essa interpretação positiva do imperialismo bonapartista como razão decisiva para o encontro brasileiro com a civilização, na medida em que essa foi uma das causas mais importantes para a definição do romantismo europeu, forma de reação nacional, principalmente na Alemanha, contra as invasões francesas $(141)^{3}$.

É importante notar que essa visão contraditoriamente positiva (para o resto da Europa, mas não para a França) de Napoleão ou do imperialismo napoleônico aparecerá não só na revista, mas também no livro de versos de Gonçalves de Magalhães que inaugurou oficialmente o romantismo brasileiro: Suspiros poéticos e saudades.

Hélio Lopes diz que temos em Magalhães o iniciador do ciclo de exaltação napoleônica no Romantismo nacional, pois antes dele a "lembrança de Napoleão, invasor de Portugal, pesava como um castigo". Passados mais de dez anos da independência brasileira e da morte do prisioneiro de Santa Helena, o introdutor do Romantismo no Brasil podia, então, "com destemor exaltar a memória de Bonaparte, instrumento de alguma forma favorável as nossas liberdades políticas" (Lopes 278-282).

Na verdade, Lopes parece esquecer que, antes de Magalhães, Napoleão já havia sido celebrado em versos por José da Natividade Saldanha no período anterior a Independência e nos anos que imediatamente a sucederam, ainda pré-românticos. $\mathrm{O}$ poeta em questão participara de movimentos emancipatórios da colônia, como foi a Revolução Pernambucana de 1817 e a Confederação do Equador de 1824, esta de caráter separatista, em razão da qual, com as represálias sofridas pelo movimento, acabou sendo exilado. Com isso, exaltar Napoleão como ídolo no contexto préindependência de 1817 era fazer frente à persistência do domínio colonial 
em favor da emancipação e da liberdade, expondo a vergonha lusitana sob dominação napoleônica. No contexto pós-independência, era não só protestar contra a dissolução da Constituinte de 1823, a tendência absolutista e a política centralizadora do governo esboçada na Carta régia outorgada por D. Pedro I em 1824. Tratava-se, também, de fazer frente ao próprio regime monárquico adotado no país recém-independente, uma vez que Natividade Saldanha, secretário da Junta Revolucionária de 1824 e cabeça pensante do movimento, assim como demais líderes da Confederação do Equador, buscavam implantar no nordeste brasileiro uma nação independente em moldes republicanos, similar à que fora implantada na Grã-Colômbia (inclusive adotando a constituição desta) depois da independência por Bolívar. Consta, inclusive, que Natividade Saldanha chegou a lutar ao lado de Bolívar ${ }^{4}$.

No plano anedótico, conta Silvio Ferraz de Arruda que "no Brasil, como em diversos países da América Espanhola, os revolucionários da Independência tramaram" raptar Napoleão:

(...) no degredo de Santa Helena, para entregar-lhe o comando da luta pela liberdade. A miragem de seu gênio militar envolveu os revolucionários de 1817 a 1824, e os nordestinos colheram fundos, por inspiração do poeta Natividade Saldanha, para a goleta que o traria ao Brasil (...). O nome do Brasil, cuja invasão ele planejara, quando da fuga de D. João VI, figura expressamente no rol de suas últimas disposições quando deixa, em testamento, '100.000 francs au general Hogendorp au Brésil'. Hogendorp, de resto, devia estar, como estava Labatut, na conspiração do rapto de Santa Helena. E na batalha de Waterloo, segundo documenta a Sociedade de Estudos Napoleônicos da Bélgica, Napoleão, cujo famoso chapéu

4 Os ecos da Grã-Colômbia eram tão fortes no Recife que a Confederação chegou a adotar sua Constituição. Consta que Saldanha teria participado das campanhas de Bolívar, na Independência da Grã-Colômbia. Esmagada a Confederação, ele fugiu para os Estados Unidos, depois para a França e da Inglaterra foi para a Venezuela. Sérgio A. P. de Borja. "A luta pela união latino-americana (De Colombéia, passando pelo pacto $\mathrm{ABC}$, até o Mercosul. É ainda importante observar que, dentre as motivações da tentativa emancipacionista como a Confederação do Equador está a perda de prestígio político-econômico dessa região nordestina (onde se iniciou a colonização no Brasil) em benefício do sudeste onde se localizava a Corte (no Rio de Janeiro) e São Paulo, que respondia pelo principal da economia nacional com a monocultura cafeteira". 
de dois bicos molhara-se e deformara sob a intensa chuva da véspera, usa um chapéu de couro do Ceará, que lhe mandara de presente um coronel do sertão cearense, a quem o Imperador mandara libertar da prisão do Limoeiro: "e um chapéu de couro / do país dos Mourões / cobriu naquele dia / a cabeça e o destino da Europa" (86-87).

Ainda no plano do anedótico, conta-se que, em maio de 1817, certo Cruz Cabugá desembarcou na Filadélfia com 800 mil dólares na bagagem incumbido da missão de comprar armas para combater as tropas de D. João VI; convencer o governo norte-americano de apoiar a criação de uma república independente no Nordeste brasileiro e recrutar alguns antigos revolucionários franceses exilados em território americano. Com a ajuda deles, libertaria Napoleão Bonaparte, exilado na Ilha de Santa Helena, a fim de transportá-lo para o Recife, onde comandaria a referida Revolução Pernambucana, para retornar, em seguida, a Paris e reassumir o trono de imperador da França 5 .

Anedotas à parte, o fato é que a inspiração de Natividade Saldanha só deixou registro da celebração póstuma do gênio militar francês, já que o poema dedicado a Napoleão foi composto sob o impacto da notícia da morte deste, em maio de 1821, e publicado no livro intitulado Poemas oferecidos aos amigos amantes do Brasil, que saiu no ano seguinte, o que vale dizer, o ano da Independência do Brasil. Trata-se desta ode, que reproduzo na íntegra, pela dificuldade de acesso, tal como ela aparece na $2^{\mathrm{a}}$ edição de suas poesias completas em 1875 :

ODE

\section{À morte de Napoleão Buonaparte}

Ce qu'il eut de mortel s'éclipse à notre vue:

Mais de ses actions le visible flambeau,

Son nom, sa renommée en cent lieux répandue

Triomphent du tombeau.

J. B. Rousseau L. 2. Op. x. 20XSdxaOj 
Nações do mundo, parabéns! é tempo,

Volte de novo ao rosto a cor perdida:

Reis da França, [subam] já sem receio

Ao mal seguro trono.

Morreu Napoleão, raio da guerra,

Que calcou dos Bourbons o antigo assento;

Cujo nome inda mais que seus triunfos

Assombrou o universo.

Mil vezes o cingiu de eterno loiro

Em márcia lide próspera vitória;

Iena, Austerlitz, Marengo, inda fumegam, Rios de sangue correm.

Tudo foi, tudo fez não sendo nada:

Viu em monte a seus pés c'roas e cetros,

E a pátria dos Catões, Cipiões, Marcelos

Sucumbiu ao seu braço.

Já não vive, seu corpo em breve é cinza:

Mas seu nome, voando além dos tempos,

Inda fará tremer, gelar de susto,

As idades vindoiras.

Exulta, ó Albion! mas, ah! receia

Que o filho deste herói, crescendo a idade,

Para vingar seu pai não te reduza

Em pouco tempo a cinzas (Natividade Saldanha 84-85).

A ode se abre com uma epígrafe do poeta e dramaturgo Jean-Baptiste Rousseau (famoso nos séculos XVII-XVIII por suas cantatas e epigramas) que trata da imortalização do nome e das ações grandiosas que triunfam no além-tumulo sobre a perecibilidade da vida, tema convencional que o poema tratará de desdobrar. Os versos se abrem de forma irônica, parabenizando as Nações do Mundo e os reis de França (particularmente os Bourbons) que podem voltar a tomar assento com a morte de Napoleão. Mas, para reforçar a ironia, logo adverte que se trata de um mal seguro trono... Depois de evocar a trajetória de glórias e retomar o tema da posteridade do nome, a ode finda por se voltar à Inglaterra exultante, advertindo-a para que receasse o risco de uma vingança futura que poderia ser levada 
a cabo pelo filho e herdeiro do homenageado. Como é sabido, Bonaparte teve um filho com sua segunda esposa, Maria Luísa da Áustria, intitulado Rei de Roma, depois Príncipe de Parma, para só ser proclamado Napoleão II ao fim dos Cem dias e, por último, nomeado duque de Reichstadt por seu avô imperador austríaco.

Falar do Fils de l'homme representou um grau suplementar na mística napoleônica e por isso, como veremos, ele foi evocado em mais de um dos poemas românticos brasileiros comentados aqui. Por ora, importa notar com Paul Bénichou que, por algum tempo, acalentou-se a esperança em relação ao filho do imperador, criando-se a imagem do Aiglon (como ficou postumamente conhecido o Rei de Roma) que voltaria a portar o raio que o Cesar pai deixou cair em Waterloo (315)... Chegou-se mesmo a lhe conferir quase o papel do Redentor na mística messiânica que se alimentou em torno da figura de Napoleão, como se vê em românticos como Nerval -e da qual também trataremos adiante-.

O filho de Napoleão volta a ser referido no já citado poema de Gonçalves de Magalhães, do qual eu gostaria de comentar agora outros aspectos, deixando essa passagem para tratar bem mais adiante.

"Napoleão em Waterloo" se inscreve na linha da poesia meditativa sobre paisagens ou sítios históricos, gênero caro à inspiração romântica. Recorrendo aqui ao velho tópos do compositio loci, o eu lírico entrega-se à observação detida de um cenário natural ou de um sítio histórico para recompor, por força da memória ou da imaginação, os eventos ou sucessos de outrora. No poema de Magalhães, a ocasião que suscita sua meditação em versos é fruto de uma viagem feita em 18 de Junho de 1836 (data do poema) justamente ao vilarejo belga de Waterloo onde sabemos se deu a grande derrota histórica do exército napoleônico. Como é próprio do gênero e da tópica em questão, a ênfase dada aos marcadores espaciais ("Eis aqui o lugar onde..."; "Aqui morreram de Marengo os bravos!..."; “...o peregrino/ Que indagador visita estes lugares..."). Serve de ponto de apoio para o espertar da mente, emulando ou suscitando os acontecimentos que aí transcorreram.

Longe de considerar o significado da subida do corso "ao poder, com a negação dos ideais revolucionários de 1789, tornando-se um homem vulgar, como terá dito Beethoven, ao fazer-se imperador", o que mais impressionou Magalhães e demais românticos brasileiros foi o homem caído. Como nota ainda Lopes, foi “(...) o desterro de Santa Helena e a 
morte no exílio o pretexto para os poetas recordarem as glórias passadas e a grandeza do homem, derrubador e construtor de nações à ponta de espada. A desgraça de Napoleão fez esquecer suas arbitrariedades e crimes" (280).

Vimos que isso se confirma também na ode de Saldanha, desconsiderada por Lopes, mas igualmente concebida em função da morte do Imperador francês. O fato não é exclusivo dos poetas brasileiros. Como nota Bénichou, a lenda napoleônica eclodiu entre os românticos franceses imediatamente após o fracasso e a morte do Herói e espraiouse pela tradição popular, conferindo dimensões sobre-humanas ao imperador e seu destino.

Voltando a "Napoleão em Waterloo", a ênfase dada à grandiosidade e à superioridade do César de flagrada na derrocada, por força mesmo do contraste ou do contransenso tão caro ao imaginário romântico, se evidencia logo na abertura, incluindo a epígrafe extraída do Memorial de Santa Helena, seguida do conjunto de imagens estelares e astronômicas com que Magalhães metaforiza o eclipsar do astro que meteoricamente alcançou o zênite:

Tout n'a manqué que quand tout avait réussi

Napoleão em S. Helena (Memorial).

Eis aqui o lugar onde eclipsou-se

O Meteoro fatal às régias frontes!

E nessa hora em que a glória se obumbrava,

Além o sol em treva se envolvia!

Rubro estava o horizonte, e a terra rubra!

Dois astros ao ocaso caminhavam;

Tocado ao seu zênite haviam ambos;

Ambos iguais no brilho; ambos na queda

Tão grandes como em horas de triunfo!

Waterloo!... Waterloo!... Lição sublime

Este nome revela à Humanidade!

"Lição sublime" define com precisão não só a trajetória ascensional do grande líder francês, mas também o procedimento retórico com que sua imagem é construída, sinalizando o redirecionamento do sublime operado pelos românticos, que o desloca do plano dos grandes espetáculos 
naturais, não raramente vistos como expressão do poder divino, e dos seres de exceção ou sobre-humanos (como deuses e semideuses), para o horizonte da história, a fim de caracterizar seres de exceção, seja no domínio do pensamento e da arte (como o gênio romântico), seja no da política: no primeiro caso, temos Shakespeare ou Victor Hugo, por exemplo; no segundo, Napoleão. Assim, o que antes era a encarnação da própria desmesura e do poder que nos atrai e nos ameaça, representado seja pelo sublime ideal (associado a Deus e suas filiais metafísicas), pelo sublime sentimental (sinalizando a impossibilidade da palavra de traduzir o inefável e o profundo das emoções) ou pelo sublime natural (os grandes espetáculos da natureza, como as tempestades violentas, a imensidão do oceano revolto, as cordilheiras, o infinito, a águia rasgando o céu etc), passa a ser aplicado diretamente, ou a servir como termo de comparação, para caracterizar personalidades históricas que transcendem os limites do humano. Napoleão é, desse modo, hiperbolicamente definido por Magalhães como "herói de mil batalhas", cujo "braço é tempestade, a espada é raio". Sua trajetória ascensional, tudo abarcando sob seu domínio, permite compará-lo à "águia sublime/ que devassava o céu com voo altivo/ desde as margens do Sena até ao Nilo,/ assombrando as Nações co'as largas asas". Seu "exército invencível", os "bravos de Marengo", são comparados à erupção do Vesúvio e assim por diante. Mesmo no momento em que é vencido e se entrega, o grande César é figurado como um leão magnânimo instalado no cimo de um rochedo a meditar, ouvindo, inabalável, as vagas fúnebres do mar revolto. Dirão ainda os versos sobre esse ser "sobranceiro a tudo", levando adiante o agenciamento de imagens e metáforas ascensionais características do sublime, que "Jamais, jamais mortal subiu tão alto!", pois "Acima d'ele Deus, - Deus tão somente!".

E é em diálogo direto com o divino que se busca a resposta para a queda fatal desse que "ao céu se eleva", tal como sua estátua de bronze sobre a coluna de Vendôme. A interpelação reiterada do divino ("Oh! Por que não venceu?") aventa duas hipóteses como causa da derrocada: "Foi destino, ou traição?”. As duas, de certo modo, são acatadas (contrapondo, na segunda hipótese, os reis traidores e os mil pigmens rivais à figura gigantesca de Bonaparte), porém a primeira se sobrepõe. Quem assume a VOz poética e responde diretamente ao grande líder dando um basta à sua augusta missão é Deus, que reconhece Sua própria glória na glória de Napoleão: 
Mas invencível mão lhe toca o peito!

É a mão do Senhor! Barreira ingente;

Basta, guerreiro! Tua glória é minha;

Tua força em mim está. Tens completado

Tua augusta missão. - És homem; - pára.

A intervenção divina se faz, portanto, no sentido de impor um limite para esse ser de exceção que, apesar de tão próximo da divindade, não deixa de ser... humano! Nota Lopes sobre essa passagem, que "a razão puxa as rédeas ao entusiasmo, e o cortesão (...) bem-comportado nesse poeta sempre indeciso em penetrar além das linhas da aventura romântica reconhece a condição humana de Napoleão" (280). Diferentemente de Magalhães, outros românticos brasileiros que cultuaram Napoleão ousarão ir mais longe.

Assim ocorre com Fagundes Varela, poeta de transição, no final da $2^{\mathrm{a}}$. geração romântica no Brasil, que, em Voz̧es d'América, também optou por flagrar o Corso em seu exílio, numa ilha de Santa Helena figurada como uma ambientação soturna, algo gótica em que:

Tremem convulsas as plagas

Bravias lutam as vagas,

Solta o vento horríveis pragas

Nos cendais da escuridão;

Mas nas torvas penedias

Entre fundas agonias...

Nessa ilha isolada de "negros mares banhadas" e "de prantos banhando o chão", em meio à convulsão dos elementos naturais, a figura meio fantasmática da sombra exilada de Bonaparte chega ela própria a proclamar: "Entre os altares fui Deus". Lopes afirma que tal arrogância teria sido abrandada na segunda versão do poema, publicada em Cantos meridionais com o título de "O espectro de Santa Helena", em que tal verso é substituído por "Deixei meu poema escrito,/grande como a criação". Essa versão, entretanto, na exclui a primeira, publicada em Cantos d'América, que continuou a figurar nas edições de suas Poesias completas. Afora isso, se houve atenuação na substituição do verso em questão, o fato é que, mesmo na segunda versão, persiste a equiparação de Napoleão a Deus, duas oitavas depois no poema, embora não seja mais o próprio Corso quem se autonomeie com tal, mas é reconhecido assim pelas caravanas de 
romeiros que por ele passavam nos desertos e "às solidões perguntavam: - É este o deus Napoleão?” (Fagundes Varella 100).

Há, além disso, no poema em que a voz é delegada ao próprio homenageado a afirmação categórica repetida ao modo de refrão, com variações, no fecho de cada oitava: "- Eu inda sou Napoleão... - E sempre serei Napoleão... - Ab! inda sou Napoleão.... - E sempre fui Napoleão...”. Até que no derradeiro verso do poema, o reconhecimento generalizado faz ecoar: "Tudo fala - Napoleão!” (Fagundes Varela 99-102). Essa certeza da posteridade é ainda configurada por meio de uma apropriação muito particular da tópica horaciana da perenidade da poesia (exegesi monumentum), depois de Napoleão equiparar seus feitos gloriosos a um poema escrito sobre titãs de granito nos vastos plainos do Egito. Levando adiante a referida tópica, dirão ainda os versos:

\section{(...)}

Nem dos bronzes da memória,

Nem das páginas da história

Meus feitos se apagarão;

(...)

Da coluna de Vendôme,

O bronze, o tempo consome,

Porém não apaga o nome

Que tem por bronze a amplidão.

(...)

E serei! do céu, da glória,

Nem dos bronzes da memória

Nem das páginas da história

Meus feitos se apagarão!

(...)

A consciência quase arrogante da posteridade converge com sua pretensa equiparação com o divino, que reverbera ainda naquela exigência hiperbólica do poeta sublime que, diz Jonathan Culler (78-79), é capaz de interpelar os elementos personificados da natureza convulsa e exigir que eles falem, a fim de testemunhar sua grandeza e perenidade:
(...)
Dizei, auras do Ocidente, Dizei, tufão inda quente 


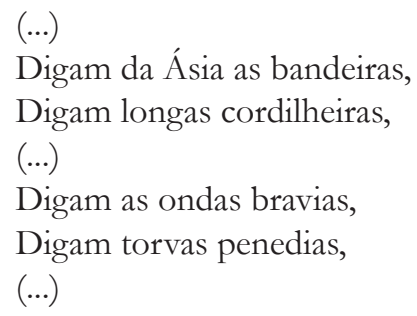

Assim como seu amigo Varella, Castro Alves, principal representante da terceira geração romântica, abolicionista e liberal, também "não titubeia no endeusamento de Napoleão" (Fagundes Varela 280), como diz Lopes, que cita como exemplo o seguinte verso de "Oitavas a Napoleão": "Deus caído do trono dos mais deuses...". Não se pode deixar de notar, entretanto, que essas oitavas são, na verdade, tradução do poema de Abigaíl Lozano, poeta venezuelano e não espanhol, como erroneamente faz supor Lopes. Sobre este poeta que foi também deputado ligado ao partido conservador e cônsul da Venezuela em Paris, disse duramente Menéndez Pelayo:

Abigaíl Lozano (que era varón, a pesar de su nombre femenino), es, sin duda, uno de los más huecos y desatinados poetas que en ninguna parte pueden encontrarse. Sus composiciones son un conjunto de palabras sonoras, que halagan por un momento el oído y dejan vacio de toda forma el entendimiento. Para él la poesía no era más que el arte de hacer versos rimbombantes y estrepitosos. Se leen sus odas a Bolívar, y nada se encuentra que no pueda aplicarse por igual a cualquier otro héroe o a cualquier otro asunto, porque el autor no concreta ni determina nada. (...) En otros versos todavía más absurdos, compara a Bolívar con Jehová, que sacó los mundos de la nada (14).

Como se vê, a deificação era procedimento analógico comum nesse tipo de poesia laudatória do Romantismo, que podia se aplicar a importantes líderes como Bolívar ou Napoleão sem por isso levar a considerar o poeta como absurdo, nonsense com quer Menéndez Pelayo. Na verdade, essa equiparação devia incomodar não só Pelayo, mas também a críticos católicos como Hélio Lopes, embora fosse perfeitamente admissível no imaginário romântico, segundo demonstra, mais uma vez, Bénichou quando observa que a função dita "providencial" não é de todo estranha a várias personalidades históricas, embora se vá mais longe quando se invoca a investidura messiânica do "homme du siècle". Comentando 
Quinet, Béranger e Hugo, principais fundadores da lenda poética de Napoleão, diz Bénichou, a respeito da gesta histórica que Quinet escreveu sobre o corso, que:

(...) poemas heróicos e poemas sagrados, para empregar as designações clássicas, haviam corrido juntos, separados tão somente por uma fronteira às vezes indecisa; e o romantismo cristão, igualmente, costumava mesclar em seus relatos o céu com a terra, e os mistérios divinos com a história. Este hábito se transmitiu ao humanitarismo místico, o que por outra parte fascinou com frequência a pessoa de Napoleão, considerado como agente providencial da renovação da sociedade europeia. Em Quinet, o próprio herói, meditando em Santa Helena, se proclama como tal (436-437).

Em outra passagem, dirá ainda crítico francês a esse respeito: "Por sua fé viva, por seu apostolado ecumênico, a França revolucionária ultrapassou e destronou as igrejas. Para Quinet como para outros, a França foi o Messias dos tempos novos, e teve em Waterloo o seu Gólgota" (444).

Num capítulo sugestivamente intitulado "A heresia romântica", que trata da pertinência (ou não) da qualificação do Romantismo como religião, Bénichou desdobra essa questão, registrando a convergência dos ideais revolucionários, direitos humanos e concepções cristãs, conferindo à França um papel messiânico. Diz ele:

De fato, o povo está aqui desdobrado no povo francês redentor e na humanidade redimida: sentimento então muito difundido, teologia à parte, entre os democratas franceses. Nesta ordem de ideias, não podiam ser indiferentes à prodigiosa carreira de Napoleão como missionário supremo da Religião. Ganneau o considera como "o povo feito homem", encarnação individual de certo modo do Encarnado coletivo. De modo que, no ministério messiânico do povo francês, se o 14 de julho é o Natal, o 18 de junho, data do Golgota-Waterloo, é a Sexta-Feira Santa, e as Três Gloriosas a Páscoa, ou ao menos um prelúdio da Páscoa futura da fraternidade e da unidade universais (403) .

6 Tais concepções se relacionam à "teologia do Évadah, do Povo-Deus, da Evaliberdade regeneradora e unificadora do mundo por suas dores, da França noiva de 
Volto ainda a Castro Alves, para quem essa comparação não devia causar maior espécie. Mas o fato é que essa analogia deificadora de Napoleão só comparecia na versão do poema de Lozano, que Castro Alves certamente deve ter escolhido para traduzir por afinidade de visão, além do gosto comum por uma poesia altissonante, que no caso do nosso poeta condoreiro, se explica pela aliança entre poesia e oratória feita, antes de impressa, para ser declamada em praça pública, mobilizando paixões para a causa defendida.

Já no poema de própria lavra que Castro Alves dedicou a Bonaparte, essa equiparação com Deus não comparece. Refiro-me a "As duas ilhas", título alusivo aos locais de exílio do grande líder corso e do outro grande poeta francês que o imortalizou em versos: Victor Hugo. Trata-se das ilhas de Santa Helena e Jersey que surgem como atalaias gigantes personificadas, qual Adamastor de granito, dialogando, confabulando e, ciosas de vingar as injustiças cometidas pelo "presente infame" e "pela "turba vulgar" contra aqueles a quem deram guarida, "encaram a imensidade / bradando: 'a Posteridade!"”. Mas "Deus ri-se e diz: 'Inda não!...”. Muito embora se tratem aqui de duas figuras cuja "majestade" foi arrancada "da mão de Deus", nenhum deles se confunde com Este e estão submetidos a Seus desígnios, aguardando a hora em que serão vingados.

No mais, o poema de Castro Alves busca outros qualificativos para caracterizar a grandiosidade de Napoleão, como o gigantismo e o titanismo (muitas vezes confundidos), que já compareciam nos dois poemas anteriores $^{7}$ e que aqui comparecem em versos como estes:

Napoleão, do martírio de Waterloo-Santa Helena e da próxima reabilitação universal" (Bénichou 404). Mesmo entre os sansimonistas, havia a concepção de que “"o poeta é aquele que realiza a obra de Deus, aquele que faz o edifício social: Moisés, Homero, Jesus, Maomé, Lutero etc são aqui os grandes poetas cuja obra não perece'; igualmente são nomeados, como poetas menos fundamentais, os 'fazedores de epopeias', 'os provetas, os padres da Igreja, Luís XI, Rabelais, Molière, Robespierre, Napoleão, Byron etc’. Tal lista supõe um jogo sobre a etimologia grega de 'poeta' (o que FAZ), que permite aplicar o nome aos criadores na ordem social, desvio de sentido bastante significativo" (Bénichou 273).

Dessas dimensões titânicas conferidas à figura napoleônica tratou Hélio Lopes no ensaio tantas vezes citado aqui, partindo do comentário do crítico português Vitor Manuel de Aguiar e Silva, que qualifica "o herói romântico como um rebelde que se ergue, altivo e desdenhoso, contra as leis e os limites que oprimem, que desafia a sociedade 
São - dous marcos miliários, Que Deus nas ondas plantou. Dous rochedos, onde o mundo

Dous Prometeus amarrou!...

- Acolá... (Não tenhas medo!...)

É Santa Helena - o rochedo

Desse Titã, que foi rei!...

-Ali... (Não feches os olhos!...)

Ali... aqueles abrolhos

São a ilha de Jersey!...

São eles - os dous gigantes

No século de pigmeus.

São eles - que a majestade

Arrancam da mão de Deus.

(...)

Es muito pequena, ó França, P'ra conter estes heróis...

Sim! que estes vultos augustos

Para o leito de Procustos

Muito grandes Deus traçou...

(...)

Na verdade, esse titanismo está inscrito na mesma esfera do sublime de que procede o repertório de imagens naturais inventariado mais atrás. Esfera à qual também pertence, na teoria goethiana do gênio (igualmente aplicada a Napoleão), o demonismo ou demoníaco, no sentido do daimon helênico, que, como adverte Rafael Argullol, não se confunde evidentemente com uma "apelação ao demônio", mas sim, "aquello que no podemos explicarnos por la inteligencia o por la razón" (segundo Eckermann); "un reconocimento de la existencia de potencias inescrutables para el conocimiento del hombre";

e o próprio Deus" (apud Lopes 279). Entre os próprios românticos já se encontrava o termo titanismo foi empregado para se referir a figuras míticas, lendárias ou históricas por eles cultuadas, como Prometeu, Caim, Satã, Fausto, Manfredo, além de gênios criadores como Victor Hugo e reis ou líderes como Bonaparte. 
enfim, una "aventura hacia lo oscuro, lo inaprehensible, lo desconocido" (Argullol 296). É assim que diz o autor de Fausto sobre Napoleão: “(...) fue verdadeiramente demoníaco em grado eminente y sin comparación en el mundo. (...) A los seres tan extremamente demoníacos los griegos solían situarlos entre los semidioses" (apud Argullol 296-7).

Como ainda complementa Argullol, lo "demóniaco o demoníaco goetheano no es sólo lo misterioso y oscuro, sino también lo infinito e inabarcable" (297), atributos específicos do sublime.

A imagética do sublime reaparece no último poema a ser comentado aqui que trata mais propriamente do filho de Napoleão, já mencionado mais atrás.

Assim, em três dos cinco poemas a Napoleão, comparece a figura do herdeiro. No primeiro deles, conforme vimos, Napoleão II surge como uma espécie de filho vingador da suposta injustiça bretã contra o pai, a quem viria a redimir restaurando e levando adiante a glória do império napoleônico. Escrita entre 1821-1822, em seguida da morte de Bonaparte, a ode de Natividade Saldanha ainda depositava esperanças num futuro reinado do herdeiro do gênio militar.

Já em "Napoleão em Waterloo", datado de 1836, a morte do herdeiro já havia se consumado. Gonçalves de Magalhães explora a referência à morte do filho, meio anacronicamente, da perspectiva do pai ainda exilado, instalado no alto dos rochedos em Santa Helena:

O grito ainda inocente de seu filho

Soa em seu coração, e de seus olhos

A lágrima primeira se desliza.

E de tantas coroas que ajuntara

Para dotar seu filho, só lhe resta

Esse Nome, que o mundo inteiro sabe!

Ah! Tudo ele perdeu! A esposa, o filho, A pátria, o mundo e seus fiéis soldados.

Mas firme era sua alma como o mármor,

Onde o raio batia, e recuava!

Mas se aqui, a perda do filho não compromete a imagem inabalável do pai, nos versos de Álvares de Azevedo, inscrito na $2^{\mathrm{a}}$ geração romântica 
brasileira, avessa à ideologia do nacionalismo pátrio alimentado pela geração de Magalhães, a frustração da esperança redentora representada por Napoleão II na ode de Saldanha é explorada de forma dilacerada. Essa desesperança comparece em um dos maiores poemas do Romatismo brasileiro: "Ideias íntimas". Entre os três retratos de seus ídolos, que pendem na parede de sua sala, o último a ser descrito é justamente o do filho de Napoleão:

(...) Defronte, aquele moço

Pálido, pensativo, a fronte erguida,

Olhar de Bonaparte em face Austríaca,

Foi do homem secular as esperanças.

No berço imperial um céu de Agosto

Nos cantos de triunfo despertou-o ...

As águias de Wagram e de Marengo

Abriram flamejando as longas asas

Impregnadas do fundo dos combates,

$\mathrm{Na}$ púrpura dos Césares, guardando-o.

E o gênio do futuro parecia

Predentiná-lo à glória. A história dele?

Resta um crânio nas urnas do estrangeiro ...

Um loureiro sem flores nem sementes ...

E um passado de lágrimas ... A terra

Tremeu ao sepultar-se o Rei de Roma,

Pode o mundo chorar sua agonia

E os louros de seu pai na fronte dele

Infecundos depor ... Estrela morta,

Só pode o menestrel sagrar-te prantos!

Leitor apaixonado de Victor Hugo (outro dos três ídolos retratados, mas num perspectiva irônica bem mais prosaica), Álvares de Azevedo devia conhecer bem os versos que o autor de Les chants de crépuscule (1835) compôs por ocasião da morte de Napoleón II em 1832, pois há certos traços afins a ambos os poemas (embora comum a outros tantos), que contrastam a expectativa do nascimento; a pompa que cerca os primeiros anos do herdeiro; a esperança nele depositada no sentido de levar adiante o legado do pai; a simbologia sublime costumeira encarnada pela águia; a crença no porvir (mais enfatizada nos versos hugoanos) e a certeza de glória, que com a morte prematura do herdeiro redunda em frustração, 
metaforizada pelas imagens da esterilidade e da perda do brilho estelar. À esperança da ode de Saldanha, resta ao menestrel de Álvares de Azevedo apenas o canto elegíaco (sagrando prantos). A passagem se fecha, assim, em chave de amarga ironia -ironia trágica-.

Comentando os versos acima, Hélio Lopes diz que "é sintomático Álvares de Azevedo, pouco propenso às tiradas ideológicas do liberalismo de então, cultuar menos o pai e mais o filho, aquele que recebeu o título de Rei de Roma e morreu com apenas vinte e um anos de idade. (...) Adivinha Álvares de Azevedo, cultuando a memória do filho de Napoleão, o seu próprio destino que o obrigava ao trágico lamento das estrofes de 'Se eu morresse amanhãl?"' (280-81). Tais estrofes do jovem poeta, que também morreu aos 21 anos, foram interpretados reiteradamente pela crítica em termos biográficos, como uma espécie de premonição do fim, o que é evidentemente muito discutível. Mais do que a afinidade da morte prematura, que ele não podia prever, é preferível crer que a escolha de Napoleão II, longe de ser lida em chave biografizante, pode ter a ver, na verdade, com o pessimismo e a ausência de perspectivas em relação ao contexto político europeu e o brasileiro do Segundo Reinado, de uma geração dos anos de 1850 muita afinada em espírito com Musset, Nerval e outros cadets daquela que Bénichou nomeou de École de désenchantement. E é nessa chave de amarga ironia que dou fecho a este ensaio.

BIBLIOGRAFIA

Arinos de Melo Franco, Alfonso. O indio brasileiro e a Revolução Francesa: as origens brasileiras da teoria da bondade natural. Rio de Janeiro: Topbooks, s/d. Impresso.

Argullol, Rafael. El Héroe y el Único: el espírito trágico del Romanticismo. Madrid: Taurus, 1999. Impresso.

Bénichou, Paul. L'école du désenchantement: Sainte-Beuve, Nodier, Musset, Nerval, Gautier. Paris: Gallimard, 1992. Impresso.

El tiempo de los profetas. Doctrinas de la época romántica. Trad. Aurelio Garzón del Camino. México: Fondo de Cultura Económica, 2001. Impresso.

CÂndido, António. Formação da Literatura Brasileira: Momentos Decisivos, v. 2 (1836-1880). Belo Horizonte: Itatiaia, 1981. Impresso. 
Culler, Jonathan. Teoria Literária: uma introdução. Sandra Guardini T. Vasconcelos, trad. São Paulo: Beca produções Culturais, 1999. Impresso.

De Borja, SÉrgio A. P. “A luta pela união latino-americana (De Colombéia, passando pelo pacto ABC, até o Mercosul)". <http:/ / www.sergioborja. com.br/SITE_ANTIGO_UFRGSS/colombeia.pdf >. Consultado em 13/07/2012. Web.

Fagundes Varella, L. N. Obras completes de...(org. Visconti Coaracy), v. I. Rio de Janeiro/Paris: H. Garnier Livreiro-Editor, s/d. Impresso.

Ferraz de Arruda, Sílvio. Frases célebres notáveis. São Paulo: Nobel, 1998. Impresso.

Lima, Olivera. O movimento da Independência. 1821-1822. Versão online <http:/ /www.biblio.com.br/defaultz.asp?link=http:/ / www.biblio. com.br/conteudo/oliveiralima/omovimentodaindependencia.htm> consultada em 13/07/2012. Web.

Lopes, HéLio. Letras de Minas e outros ensaios. São Paulo: EDUSP, 1997. Impresso.

Menéndez Pelayo, Marcelino. Antología de poetas hispano-americanos, vol. 2. Real Academia Española, 1893. Impresso.

Pane, Ignacio A. Antología. Presentación de Francisco Pérez-Maricevich. Asunción: El Lector, 1996. Impresso.

Pinassi, Maria OrLanda. Três devotos, uma fé, nenbum milagre. São Paulo: Ed. Unesp, 1998. Impresso.

Puntoni, Pedro. "A Confederação dos Tamoyos de Gonçalves de Magalhães: a poética da história e a historiografia do Império". Novos Estudos Cebrap 45 (jul. 1996): 119-30. Impresso.

Ribeiro, Renato Janine. "Iracema ou a Fundação do Brasil". Historiografia Brasileira em Perspectiva. Marcos Cezar Freitas, ed. São Paulo: Contexto/ USF, 1998. Impresso.

Ricupero, Bernardo. O romantismo e a ideia de nação no Brasil (1830-1870). São Paulo: Martins Fontes, 2004. Impresso.

Saldanha, José da Natividade. Poesias de... Colleccionadas, annotadas e precedidas de um estudo historico-biographico por José Augusto Ferreira da Costa. Pernambuco: Editor-Proprietario - J. W. de Medeiros, 1875. Impresso. 
Salgado Guimarães, Manuel L. "Nação e civilização nos trópicos: o Instituto Histórico e Geográfico Brasileiro e o projeto de uma História Nacional". Estudos Históricos 1 (Caminhos da historiografia) (1988): 5-27. Impresso.

Schwarcz, Lilia M. As barbas do Imperador: D. Pedro II, um monarca nos trópicos. São Paulo: Companhia das Letras, 1998. Impresso.

Treece, David. Exilados, aliados, rebeldes: o movimento indianista, a política indigenista e o Estado-Nação imperial. São Paulo: Nankin Ed./Edusp, 2008. Impresso.

Von Martius, Karl Friedrich. "Como se deve escrever a História do Brasil". Revista do IHGB. Rio de Janeiro, 6.24 (jan. 1845): 381-403. Impresso. 